\title{
Studies on the Effect of Aqueous Green Tea Extract on Lipid Profile and Vascular Reactivity in Hypercholesterolemic Albino Rats
} Mohammed Hassan El-Bakry, Ramadan Hassan Ibrahim, El-Shazly Abdelaal Mohaseb*

Department of Pharmacology, Faculty of Medicine, Al-Azhar University, Assiut, Egypt

*Corresponding author: El-Shazly Abdelaal Mohaseb, Mobile: (+20) 01144881566, E-Mail: Shazly_1234@yahoo.com

\begin{abstract}
Background: Hypercholesterolemia is one of the most important risk factors for atherosclerosis and subsequent cardiovascular disease (CVD). CVD is the leading cause of cardiovascular morbidity and mortality worldwide, currently, there is a major trend to use herbal remedies for the treatment and prevention of hypercholesterolemia.

Objective: In the present work, we investigated the effect of aqueous green tea extract on lipid profile and vascular reactivity \& changes in body weight in hypercholesterolemic albino rats

Materials and methods: Adult male albino rats were chosen as an animal model for this study. Rats were brought from animal house, Faculty of Medicine, Assiut University, Assiut, Egypt, and were maintained on a balanced diet with water supply freely in clean containers. They were kept for two weeks to adapt to the laboratory conditions before the start of the experiment. Forty age-matched male albino rats with initial body weights ranging from 200 to $220 \mathrm{~g}$ were used.

Results: In group (III \& IV), total cholesterol, LDL, and triglyceride levels were significantly decreased respectively\& HDL were significantly increased compared with the group II ( $p<0.05)$. also in group (III \& IV) the aortic contractility is decreased and aortic relaxation were significantly increased compared with the group II ( $\mathrm{p}<$ $0.05) \&$ body weight was decreased significantly $(\mathrm{p}<0.05)$ in group IV compared with the group II.

Conclusion: The results obtained by the present study showed that administration of aqueous green tea extract to the hypercholsterolemic rats has a role in improvement of plasma lipids, vascular reactivity\& body weight.
\end{abstract}

Keywords: Aqueous green tea, Lipid profile, Vascular reactivity, Hypercholesterolemic albino rats.

\section{INTRODUCTION}

Hypercholesterolemia is a condition characterized by very high levels of cholesterol in the blood ${ }^{(\mathbf{1})}$. Hypercholesterolemia is a problem faced by many societies and is a cause of concern for health professionals ${ }^{(2)}$.

The continuous ingestion of high amounts of fat seems to be directly related to hyperlipidemia in humans. Consequently, it has been tried to provoke hyperlipidemia in laboratory animals, in order to understand better the relationship between disorders in cholesterol metabolism and atherogenesis and to test possible treatments for the reduction of circulating cholesterol level ${ }^{(3)}$.

ITreatment of hyperlipidemia may be with therapeutic medicines or through natural edible materials which help to lower serum lipid levels. Natural edible materials have the advantage in that they avoid side effects often associated with medications, while still improving or healing the hyperlipidemia ${ }^{(4)}$. Green tea is a widely consumed beverage worldwide and is traditionally used in Asian countries as a medication. Green tea is produced from fresh leaves of Camellia sinensis and is not traditionally fermented ${ }^{(5)}$.

Green tea contains antioxidants and other beneficial nutrients such as protein, carbohydrates, minerals, vitamins, and flavonoid-like polyphenols. In vivo and in vitro studies have shown that green tea catechins (which belong to the family of flavonols and serve as an essential component of green tea, exert a cardioprotective effect via multiple mechanisms ${ }^{\left({ }^{(}\right)}$. Including the inhibition of oxidation, vascular inflammation, thrombogenesis, and improvement in blood lipid concentrations. Recent animal studies have revealed that green tea catechins could inhibit key enzymes involved in lipid biosynthesis and reduce the intestinal absorption of Total cholesterol, thereby improving blood lipid profiles ${ }^{(7)}$. Green tea catechins and EGCG have been reported to improve endothelial function in the spontaneous hypertensive rat and the high fat-fed mouse ${ }^{(8)}$.

\section{AIM OF THE WORK}

In the present work, we investigated the effect of aqueous green tea extract on lipid profile and vascular reactivity $\&$ changes in body weight in hypercholesterolemic albino rats.

\section{MATERIALS AND METHODS}

\section{Experimental animals:}

Forty adult male albino rats were chosen as an animal model for this study. Rats were brought from animal house, Faculty of Medicine, Assiut University, Assiut, Egypt, and were maintained on a balanced diet with water supply freely in clean containers. They were kept for two weeks to adapt to the laboratory conditions before the start of the experiment. Forty 
age-matched male albino rats with initial body weights ranging from 200 to $220 \mathrm{~g}$ were used.

\section{Drugs and chemicals:}

Acetylcholine (ACH) (Fluka, Switzerland). Green tea leaves (egypitian market). Chemical Company, USA). Norepinephrine (NE) (Sigma Chemical Company - Aldrich, USA). Cholesterol kits: (Salucea Dutch technology in life scienceNetherlands).Triglycerides kits: (Salucea Dutch technology in life science- Netherlands).High denesity lipoprotien (HDL) kits: (Salucea Dutch technology in life science- Netherlands).

\section{Experimental protocol:}

The rats were divided into four groups (10 rats each) as following:

- Group I: Normal (non-hypercholesterolemic) receiving distilled water only (control group)

- Group II: Control hypercholesterolemic (nontreated) (fed HFHC diet) for six weeks.

- Group III: Hypercholesterolemic rats treated with atorvastatin $(10 \mathrm{mg} / \mathrm{kg} /$ day $)$ orally for six weeks

- Group IV: Hypercholesterolemic rats treated with aqueous green tea extract $(100 \mathrm{mg} / \mathrm{kg} /$ day $)$ orally for six weeks.

\section{Procedures:}

\section{Procedures:}

\section{A-Experimental}

induction

of

hypercholesterolemia: Hypercholesterolemia was induced by feeding of rats high-fat high-cholesterol (HFHC) diets for six weeks. The HFHC containing (cholesterol 3\%, cholic acid $0.2 \%$, propylthiouracilum $0.5 \%$ and lard $10 \%)^{(9)}$.

B- Preparation and administration of the drug: Green tea was obtained as leaves from the special tea store. The extract was prepared according to Khan and Mukhtar ${ }^{(10)}$, by soaking 15 gm of green tea leaves in 1 L 90C of distilled water whose temperature did not exceed for $5 \mathrm{~min}$ to obtain the soluble aqueous extract. The solution was filtered to obtain the final $1.5 \%$ green tea extract. This extract was used instead of water until complete dose taken by rats. One gram of the green tea aqueous extract contains 7\% EGCG, 5\%, EGC, 2\% ECG, and $0.5 \%$ EC. The dose was $100 \mathrm{mg} / \mathrm{kg} / \mathrm{d}$ single dose given orally to rats. Atorvastatin was given orally $10 \mathrm{mg} / \mathrm{kg}$ body weight/day and reconstituted in normal saline ${ }^{(\mathbf{1 1})}$.

\section{C- Collection of blood samples:}

After six weeks of treatment rats were fasted overnight and then anaesthetized with ether by placing the rat in an anesthetic box filled with ether vapor which was maintained by periodically applying liquid ether to a cotton wool on the base of the box. When surgical stage of anesthesia was reached (judged by loss of withdrawal reflexes), the animal was removed and placed on a table and blood was collected from the retro-orbital plexus using capillary tube (0.75-1.0 $\mathrm{mm}$ internal diameter) inserted in the medial canthus medial to the eye globe. It was rapidly set to centrifuge at 5000 r.p.m for 10 minutes about half of the supernatant serum was sucked out into a clean dry glass serology tube using Pasteur pipette.

\section{D-Preparation of the isolated aortic rings:}

On the day of experiment, animals were killed by a blow on the head and cutting the throat. Abdominal and thoracic walls were opened. The thoracic aorta was dissected and cut, placed in dish containing Kreb's-Henseleit solution of the following composition (mM/L): $(\mathrm{NaCl} 118.4, \quad \mathrm{KCl} 4.69$, kH2PO4:1.17, MgSO4 1.18, $\mathrm{CaCl} 2.52$, glucose 11.10 and $\mathrm{NaHCO} 325)$ aerated with carbogen (95\% oxygen and $5 \%$ carbogen dioxide), cleaned from the surrounding attached tissues and cut into small rings (about $4 \mathrm{~mm}$ length).

The aortic rings were suspended in an isolated organ bath (30 ml capacity) containing Kreb'sHenseleit solution maintained at $37^{\circ} \mathrm{C}$ and aerated with carbogen. Aortic rings were subjected to an initial tension 1g, and were kept in the organ bath (for equilibration) for approximately 90 minutes, the physiological solution was renewed every 15 minutes. Response of the aortic rings to drugs were measured isometrically with a Grass FT O3 force-displacement transducer, and recorded on a polygraph. The viability and stability of the tissue were checked by two equal contractile responses to the same concentration of norepinephrine $\left(10^{-7}\right)$. Norepinephrine contained $1 \%$ $\mathrm{Hcl}$ to prevent auto-oxidation. Tissues were then washed several times and allowed to relax to base line level.

Cumulative dose-response curves to norepinephrine were performed on each ring; diluted solutions of norepinephrine $\left(1 \times 10^{-8}\right.$ to $1 \times 10^{-5}$ and $3 \times 10^{-8}$ to $3 \times 10^{-5}$ ) were used. During performing the doseresponse curves of norepinephrine each dose was added after reaching the plateau of the response of the previous dose. Each ring was serially washed after obtaining the maximum response to baseline and equilibrated.

For relaxation study; aortic rings were precontracted by norepinephrine $\left(10^{-6}\right)$ this concentration produced a submaximal response. When the response reached its plateau, cumulative concentration response curves of acetylcholine $\left(1 \times 10^{-}\right.$ ${ }^{8}$ to $1 \times 10^{-5}$ and $3 \times 10^{-8}$ to $3 \times 10^{-5}$ ) was done and each ring was serially washed after obtaining the maximum response to reach the baseline and equilibrated. During performing the dose-response curves of acetylcholine each dose was added after reaching the plateau of the response of the previous dose. 
5.Biochemical measurements:

\section{A - Serum cholesterol \& triglycerides measurements:}

Serum cholesterol \& triglycerides level was done by enzymatic colometric method ${ }^{(\mathbf{1 2})}$.

B - Determination of Serum High Density Lipoproteins:-

Serum high density lipoprotein (HDL) was estimated by precipitation method ${ }^{(13)}$.

C-Determination of Serum Low Density Lipoproteins:-

The serum LDL-cholesterol was estimated according to Friedewald et al. ${ }^{(13)}$.Using the following equation;LDL in $\mathrm{mg} / \mathrm{dl}=$ Total cholesterol - Triglyceride $/ 5$ HDL

6- Determination of changes in body weight: Initial body weight measurement then changes in body weight after six weeks of feeding high fat, high cholesterol diet then six weeks after treatment.

\section{Ethical approval:}

This study was conducted in accordance with ethical procedures and policies approved by Animal Care and Use Committee of Faculty of medicine, AlAzhar University, Cairo, Egypt.

\section{Statistical analysis}

Statistical analysis was done using the computer program (SPSS). The quantitative data were presented in the form of mean \pm standard error (S.E).Statistical analysis of data was performed by using one-way analysis of variance (ANOVA) followed by TukeyKramer test for differences between means. A value of $\mathrm{P}<0.05$ was used as a criterion for statistical significance.

\section{RESULTS}

Cumulative concentration-response curves elicited by NE on aortic ring preparations obtained from the normal rats, the hypercholesterolemic untreated rats, and the hypercholesterolemic rats treated with atorvastatin $(10 \mathrm{mg} / \mathrm{kg} / \mathrm{day})$ for 6 weeks. The results show that the contractile response of the aortae was increased significantly $(\mathrm{P}<0.01)$ in the hypercholesterolemic untreated rats in comparison with the normal rats, and decreased significantly $(\mathrm{P}<0.05)$ in the hypercholesterolemic rats treated with atorvastatin in comparison with the hypercholesterolemic untreated rats, but still there is a significant $(\mathrm{P}<0.05)$ increase in the response of the aortae of the hypercholesterolemic rats treated with atorvastatin as compared to the normal rats' aortae as shown in table (1).
Table (1): Effect of treatment with atorvastatin on the contractile response of the hypercholsterolemic rats isolated aortae to norepinephrine

\begin{tabular}{|c|c|c|c|}
\hline Groups & $\begin{array}{c}\text { Normal } \\
\text { untreated }\end{array}$ & $\begin{array}{c}\text { Hyper- } \\
\text { choleterole } \\
\text { mic } \\
\text { untreated }\end{array}$ & $\begin{array}{c}\text { Hyper- } \\
\text { cholsterole } \\
\text { mic treated } \\
\text { with } \\
\text { atorvastatin }\end{array}$ \\
\hline \begin{tabular}{|c|} 
Log.mo \\
lar \\
conc. of \\
NE
\end{tabular} & $\begin{array}{c}\text { Contractio } \\
n(g)\end{array}$ & $\begin{array}{c}\text { Contractio } \\
n(g)\end{array}$ & $\begin{array}{c}\text { Contractio } \\
n(g)\end{array}$ \\
\hline $1 \times 10^{-8}$ & $0.00 \pm 0.00$ & $0.8 \pm 0.05^{*}$ & $\begin{array}{c}\mathbf{0 . 2 8} \pm \mathbf{0 . 0 3} \\
* \#\end{array}$ \\
\hline $3 \times 10^{-8}$ & $0.05 \pm 0.02$ & $\begin{array}{l}0.98 \pm \\
0.03 *\end{array}$ & $\begin{array}{c}\mathbf{0 . 3 5} \pm \mathbf{0 . 0 4} \\
* \#\end{array}$ \\
\hline $1 \times 10^{-7}$ & $0.28 \pm 0.03$ & $\begin{array}{l}\text { 1.19士 } \\
0.04 *\end{array}$ & $\begin{array}{c}\mathbf{0 . 6 8} \pm \mathbf{0 . 0 4} \\
* \#\end{array}$ \\
\hline $3 \times 10^{-7}$ & $0.51 \pm 0.05$ & $\begin{array}{l}1.63 \pm \\
0.06^{*}\end{array}$ & $\begin{array}{c}\mathbf{0 . 9 6} \pm \mathbf{0 . 0 4} \\
* \#\end{array}$ \\
\hline $1 \times 10^{-6}$ & $0.79 \pm 0.06$ & $\begin{array}{l}1.98 \pm \\
0.09 *\end{array}$ & $\begin{array}{c}\mathbf{1 . 2 5} \pm \mathbf{0 . 0 6} \\
* \#\end{array}$ \\
\hline $3 \times 10^{-6}$ & $1.01 \pm 0.06$ & $\begin{array}{l}\text { 2.61 } \pm \\
0.06 *\end{array}$ & $\begin{array}{c}\mathbf{1 . 6 2} \pm \mathbf{0 . 0 5} \\
* \#\end{array}$ \\
\hline $1 \times 10^{-5}$ & $1.45 \pm 0.07$ & $\begin{array}{l}2.91 \pm \\
0.08 *\end{array}$ & $\begin{array}{c}\mathbf{2 . 0 1} \pm \mathbf{0 . 0 7} \\
* \#\end{array}$ \\
\hline $3 \times 10^{-5}$ & $1.45 \pm 0.07$ & $\begin{array}{l}\text { 2.91 } \pm \\
0.09 *\end{array}$ & $\underset{* \#}{\mathbf{2 . 0 1} \pm \mathbf{0 . 0 8}}$ \\
\hline
\end{tabular}

Each value represents mean \pm SE of $7-9$ rats.

* Significant difference from the normal untreated rats $(\mathrm{P}<0.01)$.

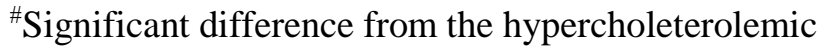
untreated rats $(\mathrm{P}<0.05)$

Cumulative concentration-response curves elicited by NE on aortic ring preparations obtained from the normal rats, the hypercholeterolemic untreated rats and the hypercholeterolemic rats treated with green tea extract $(100 \mathrm{mg} / \mathrm{kg} /$ day $)$ for 6 weeks. the results show that the contractile response of the aortae was increased significantly $(\mathrm{P}<0.01)$ in the hypercholeterolemic untreated rats in comparison with the normal rats, and decreased significantly $(\mathrm{P}<0.05)$ in the hypercholeterolemic rats treated with green tea extract in comparison with the hypercholeterolemic untreated rats, but still there is a significant $(\mathrm{P}<0.05)$ increase in the response of the aortae of the hypercholeterolemic rats treated with green tea extract as compared to the normal rats aortae as shown in table (2). 
Table (2): $\quad$ Effect of treatment with green tea extract on the contractile response of the hypercholsterolemic rats aortae to norepinephrine.

\begin{tabular}{|c|c|c|c|}
\hline Groups & Normal & $\begin{array}{c}\text { Hyper- } \\
\text { choleterolemic } \\
\text { untreated }\end{array}$ & $\begin{array}{c}\text { Hyper- } \\
\text { cholsterolemic } \\
\text { treated with } \\
\text { green tea } \\
\text { extract }\end{array}$ \\
\hline \begin{tabular}{|l} 
Log. \\
molar \\
conc \\
.$o f$ \\
$(N E)$
\end{tabular} & Contraction(g) & $\begin{array}{c}\text { Contraction } \\
(g)\end{array}$ & $\begin{array}{c}\text { Contraction } \\
(\mathrm{g})\end{array}$ \\
\hline $1 \times 10^{-8}$ & $0.00 \pm 0.00$ & $0.8 \pm 0.05^{*}$ & $0.35 \pm 0.02 * \#$ \\
\hline $3 \times 10^{-8}$ & $0.05 \pm 0.02$ & $0.98 \pm 0.03 *$ & $0.41 \pm 0.03$ *\# \\
\hline $1 \times 10^{-7}$ & $0.28 \pm 0.03$ & $1.19 \pm 0.04 *$ & $0.71 \pm 0.04$ *\# \\
\hline $3 \times 10^{-7}$ & $0.51 \pm 0.05$ & $1.63 \pm 0.06^{*}$ & $1.13 \pm 0.05 * \#$ \\
\hline $1 \times 10^{-6}$ & $0.79 \pm 0.06$ & $1.98 \pm 0.09 *$ & $1.43 \pm 0.05 * \#$ \\
\hline $3 \times 10^{-6}$ & $1.01 \pm 0.06$ & $2.61 \pm 0.06 *$ & $1.84 \pm 0.05 * \#$ \\
\hline $1 \times 10^{-5}$ & $1.45 \pm 0.07$ & $2.91 \pm 0.08 *$ & 2.150 .07 *\# \\
\hline $3 \times 10^{-5}$ & $1.45 \pm 0.07$ & $2.91 \pm 0.09 *$ & $2.15 \pm 0.08 * \#$ \\
\hline
\end{tabular}

Each value represents mean \pm SE of $7-9$ rats.

* Significant difference from the normal untreated rats $(\mathrm{P}<0.01)$.

"Significant difference from the hypercholsterolemic untreated rats $(\mathrm{P}<0.05)$

Cumulative concentration-response curves elicited by Ach on NE precontracted aortic ring preparations obtained from the normal rats, the hypercholsterolemic untreated rats and the hypercholsterolemic rats treated with atorvastatin (10 $\mathrm{mg} / \mathrm{kg} /$ day) for 6 weeks.

The results show that the relaxant response of the aortae was decreased significantly $(\mathrm{P}<0.01)$ in the hypercholsterolemic untreated rats in comparison with the normal rats, and increased significantly $(\mathrm{P}<0.01)$ in the hypercholsterolemic rats treated with atorvastatin in comparison with the hypercholsterolemic untreated rats, but still there was a significant $(\mathrm{P}<0.05)$ decrease in the response of the aortae of the hypercholsterolemic rats treated with atorvastatin as compared to the normal rats aortae as shown in table (3).
Table (3): Effect of treatment with atorvastatin on the relaxant response of the hypercholsterolemic rats isolated aortae to acetylcholine.

\begin{tabular}{|c|c|c|c|}
\hline Groups & Normal & $\begin{array}{c}\text { Hyper- } \\
\text { cholsterole } \\
\text { mic } \\
\text { untreated }\end{array}$ & $\begin{array}{c}\text { Hyper- } \\
\text { cholsterolem } \\
\text { ic treated } \\
\text { with } \\
\text { atorvastatin }\end{array}$ \\
\hline $\begin{array}{c}\text {-Log.molar } \\
\text { conc. of } \\
\text { Ach }\end{array}$ & $\begin{array}{l}\text { Relaxation } \\
(\% \text { of } \\
\text { residual } \\
\text { tone })\end{array}$ & $\begin{array}{l}\text { Relaxation } \\
(\% \text { of } \\
\text { residual } \\
\text { tone })\end{array}$ & $\begin{array}{l}\text { Relaxation } \\
\text { (\% of } \\
\text { residual } \\
\text { tone) }\end{array}$ \\
\hline$\overline{1 \times 10^{-8}}$ & $\begin{array}{c}80.1 \pm \\
1.4 \\
\end{array}$ & $\begin{array}{c}100.0 \pm 0.0 \\
*\end{array}$ & $91.4 \pm 1.4 * \#$ \\
\hline $3 \times 10^{-8}$ & $\begin{array}{c}70.2 \pm \\
1.3\end{array}$ & $\begin{array}{c}97.8 \pm 1.1 \\
*\end{array}$ & $79.5 \pm 1.4$ *\# \\
\hline $1 \times 10^{-7}$ & $\begin{array}{c}50.2 \pm \\
1.2\end{array}$ & $\begin{array}{c}88.5 \pm 1.2 \\
*\end{array}$ & $68.1 \pm 1.3 * \#$ \\
\hline $3 \times 10^{-7}$ & $\begin{array}{c}41.4 \pm \\
1.2\end{array}$ & $\begin{array}{c}79.8 \pm 1.3 \\
*\end{array}$ & $51.8 \pm 1.4 * \#$ \\
\hline $1 \times 10^{-6}$ & $\begin{array}{c}30.3 \pm \\
1.4\end{array}$ & $\begin{array}{c}69.4 \pm 1.3 \\
* \\
\end{array}$ & $45.6 \pm 1.4$ *\# \\
\hline $3 \times 10^{-6}$ & $\begin{array}{c}23.6 \pm \\
1.5\end{array}$ & $\begin{array}{c}65.5 \pm 1.4 \\
*\end{array}$ & $38.4 \pm 1.5 * \#$ \\
\hline $1 \times 10^{-5}$ & $\begin{array}{c}17.2 \pm \\
1.3\end{array}$ & $\begin{array}{c}59.1 \pm 1.4 \\
*\end{array}$ & $30.8 \pm 1.6 * \#$ \\
\hline $3 \times 10^{-5}$ & $\begin{array}{c}17.2 \pm \\
1.2\end{array}$ & $\underset{*}{59.1} \pm 1.2$ & $30.8 \pm 1.4$ *\# \\
\hline
\end{tabular}

Each value represents mean \pm SE (standard error) of $7-9$ rats.

*Significant difference from the normal untreated rats $(\mathrm{P}<0.01)$.

\# Significant difference from the hypercholsterolemic untreated rats $(\mathrm{P}<0.01)$.

Cumulative concentration-response curves elicited by Ach on NE precontracted aortic ring preparations obtained from the normal rats, the hypercholsterolemic untreated rats and the hypercholsterolemic rats treated with green tea extract $(100 \mathrm{mg} / \mathrm{kg} /$ day) for 6 weeks.

The results show that the relaxant response of the aortae was decreased significantly $(\mathrm{P}<0.001)$ in the hypercholsterolemic untreated rats in comparison with the normal rats, and increased significantly $(\mathrm{P}<$ 0.01 ) in the hypercholsterolemic rats treated with green tea extract in comparison with the hypercholsterolemic untreated rats, but still there was a significant $(\mathrm{P}<0.01)$ decrease in the response of the aortae of the hypercholsterolemic rats treated with green tea extract as compared to the normal rats aortae as shown in table (4). 
Table (4): $\quad$ Effect of treatment with green tea extract on the relaxant response of the hypercholsterolemic rats isolated aortae to acetylcholine.

\begin{tabular}{|c|c|c|c|}
\hline Groups & Normal & $\begin{array}{l}\text { Hyperchol } \\
\text { sterolemic } \\
\text { untreated }\end{array}$ & $\begin{array}{c}\text { Hyperchols } \\
\text { terolemic } \\
\text { treated } \\
\text { with green } \\
\text { tea extract }\end{array}$ \\
\hline $\begin{array}{c}\text { Log.molar } \\
\text { conc.of } \\
\text { (Ach) }\end{array}$ & $\begin{array}{l}\text { Relaxation } \\
\text { (\% of } \\
\text { residual } \\
\text { tone) }\end{array}$ & $\begin{array}{l}\text { Relaxation } \\
\text { (\% of } \\
\text { residual } \\
\text { tone) }\end{array}$ & $\begin{array}{c}\text { Relaxation } \\
\text { (\% of } \\
\text { residual } \\
\text { tone) }\end{array}$ \\
\hline$\overline{12 \times 10^{-8}}$ & 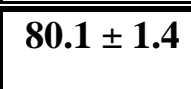 & $\begin{array}{c}100.0 \pm 0.0 \\
*\end{array}$ & $92.2 \pm 1.4 * \#$ \\
\hline $3 \times 10^{-8}$ & $70.2 \pm 1.3$ & $\begin{array}{c}97.8 \pm 1.1 \\
*\end{array}$ & $\underset{\#}{88.4 \pm 1.2} *$ \\
\hline $1 \times 10^{-7}$ & $50.2 \pm 1.2$ & $\begin{array}{c}88.5 \pm 1.2 \\
*\end{array}$ & $\underset{\#}{80.1} \pm 1.4 *$ \\
\hline $3 \times 10^{-7}$ & $41.4 \pm 1.2$ & $\begin{array}{c}79.8 \pm 1.3 \\
*\end{array}$ & $63.1 \pm 1.3 * \#$ \\
\hline $1 \times 10^{-6}$ & $30.3 \pm 1.4$ & $\begin{array}{c}69.4 \pm 1.3 \\
*\end{array}$ & $54.4 \pm 1.2 * \#$ \\
\hline $3 \times 10^{-6}$ & $23.6 \pm 1.5$ & $\begin{array}{c}65.5 \pm 1.4 \\
*\end{array}$ & $50.3 \pm 1.5$ * \# \\
\hline $1 \times 10^{-5}$ & $17.2 \pm 1.3$ & $\begin{array}{c}59.1 \pm 1.4 \\
*\end{array}$ & $42.1 \pm 1.7$ * \# \\
\hline $3 \times 10^{-5}$ & $17.2 \pm 1.2$ & $\begin{array}{c}59.1 \pm 1.2 \\
*\end{array}$ & $42.1 \pm 1.4 * \#$ \\
\hline
\end{tabular}

Each value represents mean \pm SE of $7-9$ rats.

*Significant difference from the normal rats $(\mathrm{P}<0.01)$.

"Significant difference from the hypercholsterolemic untreated rats $(\mathrm{P}<0.01)$.

The results show that serum cholesterol was increased significantly $(\mathrm{P}<0.01)$ in the hypercholsterolemic untreated rats in comparison with the normal rats. In the hypercholsterolemic rats treated with atorvastatin $(10 \mathrm{mg} / \mathrm{kg} /$ day $)$ for 6 weeks, serum cholesterol was decreased significantly $(\mathrm{P}<0.01)$ in comparison with the hypercholsterolemic untreated rats, In the hypercholsterolemic rats treated with green tea extract $(100 \mathrm{mg} / \mathrm{kg} / \mathrm{day})$ for 6 weeks, serum cholesterol was decreased significantly $(\mathrm{P}<0.01)$ in comparison with the hypercholsterolemic untreated rats, but still there was a significant $(\mathrm{P}<0.05)$ increase as compared to the normal rats as shown in table as shown in table (5).
Table (5): Effect of treatment with atorvastatin \& green tea extract on serum cholesterol of the hypercholsterolemic rats.

\begin{tabular}{|l|l|}
\hline \multicolumn{1}{|c|}{ Groups } & \multicolumn{1}{|c|}{$\begin{array}{c}\text { Serum cholesterol } \\
(\mathbf{m g} / \mathbf{d l})\end{array}$} \\
\hline \hline Normal & $98.62 \pm 3.13$ \\
\hline Hypercholsterolemic untreated & $220.28 \pm 3.58 *$ \\
\hline $\begin{array}{l}\text { Hypercholsterolemic treated } \\
\text { with atorvastatin }\end{array}$ & $111.57 \pm 3.04 * \#$ \\
\hline $\begin{array}{l}\text { Hypercholsterolemic treated } \\
\text { with green tea extract }\end{array}$ & $133.14 \pm 3.04 * \#$ \\
\hline
\end{tabular}

Each value represents the mean \pm SE (standard error) of $7-9$ animals.

* Significant difference from the normal rats (P $<0.01$ ).

\# Significant difference from the hypercholsterolemic untreated rats $(\mathrm{P}<0.01)$.

The results show that serum triglycerides were increased significantly $(\mathrm{P}<0.01)$ in the hypercholsterolemic untreated rats in comparison with the normal rats. In the hypercholsterolemic rats treated with atorvastatin $(10 \mathrm{mg} / \mathrm{kg} /$ day $)$ for 6 weeks, serum triglycerides was decreased significantly $(\mathrm{P}<0.01)$ in comparison with the hypercholsterolemic untreated rats, in the hypercholsterolemic rats treated with green tea extract $(100 \mathrm{mg} / \mathrm{kg} /$ day) for 6 weeks, serum triglycerides was decreased significantly $(\mathrm{P}<0.01)$ in comparison with the hypercholsterolemic untreated rats but still there is a significant $(\mathrm{P}<0.05)$ increase as compared to the normal rats as shown in table (6).

Table (6): Effect of treatment with atorvastatin \& green tea extract, on serum triglycerides of the hypercholsterolemic rats.

\begin{tabular}{|l|c|}
\hline \multicolumn{1}{|c|}{ Groups } & $\begin{array}{c}\text { Serum } \\
\text { triglycerides } \\
\text { (mg/dl) }\end{array}$ \\
\hline \hline Normal & $67.87 \pm 2.65$ \\
\hline Hypercholsterolemic untreated & $167.87 \pm 3.01 *$ \\
\hline $\begin{array}{l}\text { Hypercholsterolemic treated } \\
\text { with atorvastatin }\end{array}$ & $89.12 \pm 2.48 * \#$ \\
\hline $\begin{array}{l}\text { Hypercholsterolemic treated } \\
\text { with green tea extract }\end{array}$ & $\begin{array}{c}124.37 \pm 2.48 \\
* \#\end{array}$ \\
\hline
\end{tabular}

Each value represents the mean \pm SE (standard error) of $7-9$ animals.

* Significant difference from the normal rats $(\mathrm{P}<$ $0.01)$.

\# Significant difference from the hypercholsterolemic untreated rats $(\mathrm{P}<0.01)$. 
The results show that serum HDL was decreased significantly $(\mathrm{P}<0.01)$ in the hypercholsterolemic untreated rats in comparison with the normal rats. In the hypercholsterolemic rats treated with atorvastatin, serum HDL was increased significantly $(\mathrm{P}<0.01)$ in comparison with the hypercholsterolemic untreated rats, In the hypercholsterolemic rats treated with green tea extract, serum HDL was increased significantly $(\mathrm{P}<$ $0.05)$ in comparison with the hypercholsterolemic untreated rats, but still there was a significant $(\mathrm{P}<$ $0.05)$ decrease as compared to the normal rats as shown in table (7).

Table (7): Effect of treatment with atorvastatin \& green tea extract on serum HDL of the hypercholsterolemic rats.

\begin{tabular}{||l|c||}
\hline \multicolumn{1}{|c|}{ Groups } & $\begin{array}{r}\text { Serum HDL } \\
(\mathbf{m g} / \mathbf{d l})\end{array}$ \\
\hline \hline Normal & $48.14 \pm 0.83$ \\
\hline Hypercholsterolemic untreated & $22.14 \pm 0.87 *$ \\
\hline $\begin{array}{l}\text { Hypercholsterolemic treated } \\
\text { with atorvastatin }\end{array}$ & $38.25 \pm 0.63 * \#$ \\
\hline $\begin{array}{l}\text { Hypercholsterolemic treated } \\
\text { with green tea extract }\end{array}$ & $33.71 \pm 0.63 * \#$ \\
\hline
\end{tabular}

Each value represents the mean $\pm \mathrm{SE}$ (standard error) of $7-9$ animals.

* Significant difference from the normal rats $(\mathrm{P}<$ $0.01)$.

\# Significant difference from the hypercholsterolemic untreated rats $(\mathrm{P}<0.05)$.

The results show that serum LDL was increased significantly $(\mathrm{P}<0.01)$ in the hypercholsterolemic untreated rats in comparison with the normal rats. In the hypercholsterolemic rats treated with atorvastatin, serum LDL was decreased significantly $(\mathrm{P}<0.01)$ in comparison with the hypercholsterolemic untreated rats \& In the hypercholsterolemic rats treated with green tea extract, serum LDL was decreased significantly $(\mathrm{P}<$ $0.01)$ in comparison with the hypercholsterolemic untreated rats, but still there is a significant $(\mathrm{P}<0.05)$ increase as compared to the normal rats as shown in table (8).
Table (8): Effect of treatment with atorvastatin \& green tea extract on serum LDL of the hypercholsterolemic rats.

\begin{tabular}{|l|l|}
\hline \multicolumn{1}{|c|}{ Groups } & \multicolumn{1}{|c|}{$\begin{array}{c}\text { Serum LDL } \\
(\mathbf{m g} / \mathbf{d l})\end{array}$} \\
\hline \hline Normal & $36.91 \pm 1.46$ \\
\hline Hypercholsterolemic untreated & $164.57 \pm 1.03 *$ \\
\hline $\begin{array}{l}\text { Hypercholsterolemic treated with } \\
\text { atorvastatin }\end{array}$ & $55.5 \pm 1.7 * \#$ \\
\hline $\begin{array}{l}\text { Hypercholsterolemic treated with } \\
\text { green tea extract }\end{array}$ & $74.42 \pm 1.7 * \#$ \\
\hline
\end{tabular}

Each value represents the mean \pm SE (standard error) of $7-9$ animals.

* Significant difference from the normal rats $(\mathrm{P}<0.01)$. \# Significant difference from the hypercholsterolemic untreated rats $(\mathrm{P}<0.01)$.

The results showed that body weight was increased significantly $(\mathrm{P}<0.01)$ in the hypercholsterolemic rats non treated in comparison with the normal rats, with no significant $(\mathrm{P}>0.05)$ difference in body weight between the hypercholsterolemic rats treated with atorvastatin (10 $\mathrm{mg} / \mathrm{kg} / \mathrm{day}$ ) for 6 weeks and the hypercholsterolemic untreated rats. in the hypercholsterolemic rats treated with green tea extract $(100 \mathrm{mg} / \mathrm{kg} /$ day $)$ for 6 weeks Body weight was decreased significantly $(\mathrm{P}<0.01)$ in comparison with hypercholsterolemic untreated rats as shown in table (9).

Table (9): $\quad$ Effect of treatment with atorvastatin \& green tea extract on body weight of the hypercholsterolemic rats

\begin{tabular}{||l|l||}
\hline \multicolumn{1}{|c|}{ Groups } & \multicolumn{1}{c|}{ Body weight $(\mathbf{g})$} \\
\hline \hline Normal & $174.42 \pm 2.5$ \\
\hline $\begin{array}{l}\text { Hypercholsterolemic } \\
\text { untreated }\end{array}$ & $199.28 \pm 2.5 *$ \\
\hline $\begin{array}{l}\text { Hypercholsterolemic } \\
\text { treated with atorvastatin }\end{array}$ & $200.14 \pm 2.1^{*}$ \\
\hline $\begin{array}{l}\text { Hypercholsterolemic } \\
\text { treated with green tea } \\
\text { extract }\end{array}$ & $148.71 .14 \pm 2.1 * \#$ \\
\hline
\end{tabular}

Each value represents the mean \pm SE (standard error) of $7-9$ animals.

*Significant difference from the normal rats $(\mathrm{P}<$ $0.01)$.

\# Significant difference from the hypercholsterolemic untreated rats $(\mathrm{P}<0.01)$ 


\section{DISCUSSION}

Hypercholesterolemia is defined as excessively high plasma cholesterol levels, and is a strong risk factor for many negative cardiovascular events. Total cholesterol levels above $200 \mathrm{mg} / \mathrm{dl}$ have repeatedly been correlated as an independent risk factor for development of peripheral vascular and coronary artery disease ${ }^{(14)}$.

Treatment of hyperlipidemia may be with therapeutic medicines or through natural edible materials which help to lower serum lipid levels. Natural edible materials have the advantage in that they avoid side effects often associated with medications, while still improving or healing the hyperlipidemia ${ }^{(\mathbf{1 5})}$.

The present work showed that the contractile response to norepinephrine (NE) was higher in the hypercholesterolemic group than that of the control group and the response to $\mathrm{ACh}$ was lower in the hypercholesterolemic group than that of the control group, and these were in agreement with the results of ${ }^{(\mathbf{1 6} \text {, }}$ 17).

Galle et al. ${ }^{(18)}$ reported that numerous studies have shown that hypercholesterolemia is associated with the development of atherosclerosis. During this process, various alterations in vascular reactivity have been observed, in particular, attenuation of endotheliumdependent vasodilations and increased responsiveness to different contractile agonists.

Our study showed that the contractile response of the aortae was decreased significantly in the hypercholsterolemic rats treated with atorvastatin in comparison with the hypercholeterolemic untreated rats and the relaxant response of the aortae was increased significantly in the hypercholsterolemic rats treated with atorvastatin in comparison with the hypercholsterolemic untreated rats.

These results were in agreement with study done by Mahmoud et al. ${ }^{(19)}$ which showed that atorvastatin protected against fructose induced hyperresponsiveness to $\mathrm{PE}$ and $\mathrm{KCl}$ in fructose fed rats indued hypercholesterolemia and insulin resistance.

These results were disagreement with Bendary (20) who showed that atorvastatin produced no significant amelioration to norepinephrine induced aortic contraction in hypercholesterolemic rats. Mahmoud $\boldsymbol{e t}$ al. ${ }^{(19)}$ also showed that atorvastatin did not prevent hyporesponsiveness to Ach in fructose fed rat's indued hypercholesterolemia and insulin resistance.

The present work showed that the contractile response of the aortae was decreased significantly in the hypercholsterolemic rats treated with green tea extract in comparison with the hypercholeterolemic untreated rats and the relaxant response of the aortae was increased significantly in the hypercholsterolemic rats treated with green tea extract in comparison with the hypercholsterolemic untreated rats

There are no available reports about the effect of green tea extract on isolated aortae of experimentally induced hypercholsterolemic rats but
The effects of green tea catechins against vascular dysfunction were studied in animals both in vitro as well as in vivo with other diseases have been documented in which our results were in agreement with it.

Such these studies as acute treatment of isolated rat thoracic aortas with green tea catechins resulted dose-dependent vasodilation against phenylephrineinduced contractions ${ }^{(21,22)}$.

Song et al. (23) showed that in rats with hypertention induced by hypercholesterolaemia green tea enhanced vasorelaxation induced by acetylcholine in rat aortic rings.

In spontaneously hypertensive rats, daily supplementation of $200 \mathrm{mg}$ EGCG/kg for 3 weeks significantly improved vascular tone of mesenteric vascular beds and reduced systolic blood pressure ${ }^{(\mathbf{1 6})}$.

There is convincing evidence from animal studies that green tea catechins exert beneficial effects against endothelial dysfunction by increasing $\mathrm{NO}$ production. Other studies provided evidence that EGCG resulted in endothelium- and NO-dependent vasodilation in rat aortic rings ${ }^{(24,25)}$.

Our study showed that serum total cholesterol, LDL, Tg, was increased significantly in the hypercholsterolemic untreated rats in comparison with the normal rats and serum HDL was decreased significantly in the hypercholsterolemic untreated rats in comparison with the normal rats. These results were in agreement with the results obtained by other workers ${ }^{(9,26)}$.

Our study showed that in the hypercholsterolemic rats treated with atorvastatin serum cholesterol LDL, Tg, was decreased significantly and serum HDL was increased significantly in comparison with the hypercholsterolemic untreated rats.

These results were in agreement with the results obtained by Hamed et al. ${ }^{(27)}$, Chennappaneskar and Lathadevi ${ }^{(28)}$.

Our study showed that in the hypercholsterolemic rats treated with green tea extract serum total cholesterol, LDL, Tg was decreased significantly and serum HDL was increased significantly in comparison with the hypercholsterolemic untreated rats.

These results were in agreement with the results obtained by Muramatsu et al. ${ }^{(29)}$ and Amanolahi et al. ${ }^{(30)}$ and the clinical studies done by Nagao et al. ${ }^{(31)}$ and Batista et al. ${ }^{(32)}$.

These results were disagreement with the clinical reports obtained by Princen et al. ${ }^{(33)}$ and Chan et al. ${ }^{(34)}$ whom showed that the reduction in plasma lipid profile not related to green tea. Moreover a clinical study done by Zheng $\boldsymbol{e t}$ al. ${ }^{(35)}$ showed that the administration of green tea beverages or extracts resulted in significant reductions in serum TC and LDL-cholesterol concentrations, but no effect on HDL cholesterol was observed. These effects may be due to 
anti-hyperlipidemic, anti-oxidative and antiatherosclerotic effects of green tea ${ }^{(36)}$.

The present work showed that body weight was increased significantly in the hypercholsterolemic untreated rats in comparison with the normal rats. These results were in agreement with the results obtained by Amanolahi et al. ${ }^{(30)}$ and Mohamed et al. (37)

The present work showed that In the hypercholsterolemic rats treated with green tea extract body weight was decreased significantly in the in comparison with the hypercholsterolemic untreated rats. These results were in agreement with the results obtained by Amanolahi et al. ${ }^{(30)}$.

Green tea is widely marketed for the use of reduction of weight or obesity and also for life style related health problems ${ }^{(37)}$. Weight reduction by green tea might be due to reduced digestibility and an increase in energy expenditure and fat oxidation through $\beta$ adrenoceptor activated thermogenesis of brown adipose tissue ${ }^{(38)}$. Inhibited lipid absorption from meals might be other reason for reduced weight gain ${ }^{(39)}$.

\section{CONCLUSION}

The results obtained by the present study showed that the administration of aqueous green tea extract either treatment or prophylactic to the hypercholesterolemic rats has a role in the improvement of plasma lipids, body weight, and vascular reactivity. The mechanism of these effects may be attributed to its anti-hyperlipidemic effect \& NO production, further detailed investigations are necessary to know the exact mechanism.

\section{REFERENCES}

1. Adaramoye $\mathrm{O}$, Akintayo $\mathrm{O}$, Achem $\mathrm{J}$ et al. (2008): Lipid-lowering effects of methanolic extract of vernonia amygdalina leaves in rats fed on high cholesterol diet. Vascular health and Risk Management, 4: 235- 241.

2. Gerhardt A, Gallo N (1998): Full-fat rice bran and oat bran similarly reduce hypercholesterolemia in humans. $\mathrm{J}$ Nutr., 128, 865-869.

3. Moghadasian M, Frohlich J, McManus B (2001): Advances in experimental dyslipidemia and atherosclerosis. Lab Invest., 81: 1173-1183.

4. Yoon M, Lee H, Jeong $S$ et al. (2003): Peroxisome proliferators activated receptor alpha is involved in the regulation of lipid metabolism by ginseng. $\mathrm{Br} \mathrm{J}$ Pharmacol., 138:11295- 1302.

5. Balentine D, Wiseman S, Bouwens L (1997): The chemistry of tea flavonoids. Crit Rev Food Sci Nutr., 37:693.

6. Stangl V, Dreger H, Stangl K et al. (2007): Review Molecular targets of tea polyphenols in the cardiovascular system. Cardiovasc Res., 73:348-55.

7. Bursill C, Abbey M, Roach P (2007): A green tea extract lowers plasma cholesterol by inhibiting cholesterol synthesis and upregulating the LDL receptor in the cholesterol-fed rabbit. Atherosclerosis, 193:869398.
8. Jang H, Ridgeway S, Kim J (2013): Effects of the green tea polyphenol epigallocatechin-3-gallate on high-fat diet-induced insulin resistance and endothelial dysfunction. Am J Physiol Endocrinol Metab., 305(12):1444-1451.

9. Yue-Hui Y, Jun Y, Qing-Hua J (2013): Hypolipidemic effect of gypenosides in experimentally induced hypercholesterolemic rats. Lipids in Health and Disease, 12:154-59.

10. Khan N, Mukhtar H (2007): Tea polyphenols for health promotion. Life Sci., 81:519-533.

11.Huang C, Cen C, Wang C et al. (2014): Synergistic effects of colchicine combined with atorvastatin in rats with hyperlipidemia. Lipids Health Dis., 13: 67-73.

12. Young DS. (1995): Effect of drugs on clinical laboratory testes. $\quad 4^{\text {th }}$ ed. Pp. 190-3211. https://journals.sagepub.com/doi/abs/10.1177/00045632 9703400601

13. Friedewald W, Levy R, Fredrickson D (1972): Estimation of the concentration of low-density lipoprotein cholesterol in plasma, without use of the preparative ultracentrifuge. Clin Chem., 18(6): 499-502.

14. Stapleton A, Goodwill G, James M et al. (2010): Hypercholesterolemia and microvascular dysfunction: interventional strategies, J Inflamm (Lond), 7: 54-59.

15. Yoon M, Lee H, Jeong $S$ et al. (2003): Peroxisome proliferators activated receptor alpha is involved in the regulation of lipid metabolism by ginseng. $\mathrm{Br} \mathrm{J}$ Pharmacol., 138:11295- 1302.

16. Rosendorff C (2002): Effects of LDL cholesterol on vascular function. J Hum Hypertens, 16: 26-28.

17. Rahman E, Donia S, Naguib Y (2013): Garlic improves altered vascular reactivity and plasma lipids in high cholesterol-fed rats. Menoufia Med J., 26:35-43.

18. Galle J, Busse R, Bassenge $E$ (1991): Hypercholesterolemia and atherosclerosis change vascular reactivity in rabbits by different mechanisms. Arterioscler Thromb., 11: 1712 -1718.

19. Mahmoud M, El-Nagar M, El-Bassossy H (2012): Anti-inflammatory Effect of Atorvastatin on Vascular Reactivity and Insulin Resistance in Fructose Fed Rats Arch Pharm Res., 35: 155-162.

20. Bendary M (2004): Effect of some hypolipidemic agents on vascular reactivity of hypercholesterolemic rats. TY Jour., 10: 277-289.

21.Lim D, Lee E, Park H et al. (2003): Compari- son of green tea extract and epigallocatechin gallate on blood pres- sure and contractile responses of vascular smooth muscle of rats. Arch Pharm Res., 26: 214-23.

22.Potenza M, Marasciulo F, Tarquinio M et al. (2007): EGCG, a green tea polyphenol, improves endothelial function and insulin sensitivity, reduces blood pressure, and protects against myocardial I/R injury in SHR. Am J Physiol Endocrinol Metab., 292: 1378-87.

23. Song L, Koo M, Lau C et al. (2008): Effects of green tea on lipids, blood pressure and vasorelaxation in rats with hypercholesterolaemia-induced hypertension. Posters / International Journal of Cardiology, 125: 51-73.

24.Lorenz M, Wessler S, Follmann E et al. (2004): A constituent of green tea, epigallocatechin-3- gallate, activates endothelial nitric oxide synthase by a phosphatidylinositol-3-OH-kinase-, cAMP-dependent protein kinase-, and Akt-dependent pathway and leads to endothelial-dependent vasore- laxation. J Biol Chem., 279: 6190-5. 
25.Jochmann N, Lorenz M, Krosigk A et al. (2008): The efficacy of black tea in ameliorating endothelial func- tion is equivalent to that of green tea. Br J Nutr., 99: 863-8.

26.Samy H, Yakout E, Mohammed R et al. (2014): Hypolipidemic effect of curcumin in hypercholesterolemic rats. BVMJ., 27(2): 277- 289.

27. Hamed M, Hassanein M, Ali A et al. (2010): An Experimental Study on the Therapeutic Efficacy of the Combined Administration of Herbal Medicines with Atorvastatin against Hyperlipidemia in Rats. J Appl Sci Res., 6(11): 1730-1744.

28. Chennappaneskar H, Lathadevi G (2018): Hypolipidemic Effects of Fenugreek and AtorvastatinComparative Studyon High Fat Fed Dyslipidemic Rats. Journal of Clinical and Diagnostic Research, 12(9): 1-4.

29. Muramatsu K, Fukuyo M, Hara Y (1986): Effect of green tea catechins on plasma cholesterol level in cholesterol-fed rats J Nutr Sci Vitaminol (Tokyo), 32(6):613-22.

30.Amanolahi F, Rakhshande H (2013): Effects of ethanolic extract of green tea on decreasing the level of lipid profile in rat. Avicenna Journal of Phytomedicine, 3: 98-105.

31. Nagao T, Hase T, Tokimitsu I (2007): A green tea extract high in catechins reduces body fat and cardiovascular risks in humans. Obesity (Silver Spring), 15:1473-83.

32. Batista G, Cunha C, Scartezini M et al. (2009): Prospective double-blind crossover study of Camellia sinensis (green tea) in dyslipidemias. Arq Bras Cardiol., 93:128-34.
33.Princen H, van Duyvenvoorde W, Buytenhek R et al. (1998): No effect of consumption of green and black tea on plasma lipid and antioxidant levels and on LDL oxidation in smokers. Arterioscler Thromb Vasc Biol., 18:833-41.

34. Chan P, Fong W, Cheung Y et al. (1999): Jasmine green tea epicatechins are hypolipidemic in hamsters (Mesocricetus auratus) fed a high fat diet. J Nutr., 129:1094-101.

35.Zheng X, Xu Y, Li S et al. (2011): Green tea intake lowers fasting serum total and LDL cholesterol in adults: a meta-analysis of 14.randomized controlled trials,Am J Clin Nutr., 94:601-10.

36. Hussain M, Rava P, Walsh M et al. (2012): Multiple functions of microsomal triglyceride transfer protein. Nutr Metab., (9):14-30.

37. Mohamed A, Ibrahim W, Zaki N et al. (2019): Effectiveness of Coelatura aegyptiaca Extract Combination with Atorvastatin on Experimentally Induced Hyperlipidemia in Rats, Evidence-Based Complementary and Alternative Medicine. https://www.hindawi.com/journals/ecam/2019/9726137/

38. Wang S, Moustaid-Moussa N, Chen L et al. (2014): Novel insights of dietary polyphenols and obesity. J Nutr Biochem., 25(1):1-18.

39. Chen Y, Cheung C, Reuhl K et al. (2011): Effects of green tea polyphenol (-)-epigallocatechin-3-gallate on newly developed high-fat/western-style diet-induced obesity and metabolic syndrome in mice. J Agric Food Chem., 59(21): 11862-71. 